\title{
Normal growth, altered growth? Study of the relationship between \\ Harris Lines and bone form within a post-medieval plague cemetery (Dendermonde, Belgium, 16th century)
}

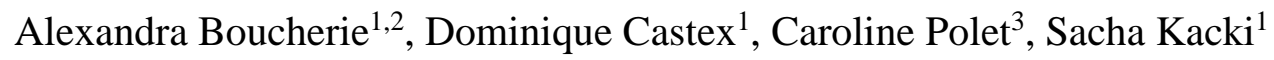 \\ ${ }^{1} \mathrm{UMR} 5199$ PACEA «Anthropologie des populations passées et présentes », CNRS, \\ University of Bordeaux, Building B8, Allée Geoffroy Saint Hilaire, CS 50023, 33615 PESSAC \\ CEDEX, France. \\ ${ }^{2}$ Department of Archaeology, Anthropology and Forensic Science, Bournemouth University, \\ Fern Barrow, Poole, BH12 5BB, UK. \\ ${ }^{3}$ Operational Directory 'Earth and History of Life', Royal Belgian Institute of Natural Sciences, \\ rue Vautier 29, 1000 Brussels, Belgium.
}

\begin{abstract}
Objectives: Harris lines (HLs) are defined as transverse mineralized lines associated with temporary growth arrest. In paleopathology, HLs are used to reconstruct health status of past populations. However, their etiology is still obscure. The aim of this article is to test the reliability of HLs as an arrested growth marker by investigating their incidence on human metrical parameters.

Methods: The study was performed on 69 individuals (28 adults, 41 subadults) from the Dendermonde plague cemetery (Belgium, 16th century). HLs were rated on distal femora and both ends of tibiae. Overall prevalence and age-at-formation of each detected lines were calculated. ANOVA analyses were conducted within subadult and adult samples to test if the presence of HLs did impact size and shape parameters of the individuals.

Results: At Dendermonde, 52\% of the individuals had at least one HL. The age-at-formation was estimated between 5 and 9 years old for the subadults and between 10 and 14 years old for the adults. ANOVA analyses showed that the presence of HLs did not affect the size of the individuals. However, significance differences in shape parameters were highlighted by HLs presence. Subadults with HLs displayed slighter shape parameters than the subadults without whereas the adults with HLs had larger measurements than the adults without.

Conclusions: The results suggest that HLs can have a certain impact on shape parameters. The underlying causes can be various, especially for the early formed HLs. However, HLs deposited around puberty are more likely to be physiological lines reflecting hormonal secretions.
\end{abstract}


Keywords: Harris lines - paleopathology - arrest of growth - growth dynamics - physiological lines

\section{Introduction}

The occurrence of transverse highly mineralized lines on bones was noted for the first time by Wegner in 1874. Then, these features were intensively analyzed through clinical and experimental studies by H.A. Harris. They were subsequently named Harris lines (HLs). Noticed in diabetic children and undernourished rats, HLs were promptly associated with episodes of arrested growth caused by unfavorable conditions during ontogenesis, i.e. infections, various diseases and nutritional deficiencies (Harris, 1931).

Harris lines are commonly described as transverse lines of increased density visible on radiographs (Harris, 1931; Park, 1964). Histologically speaking, HLs are oriented trabeculae that cross transversally the bone, and are especially present within the medullary cavity of the long bones (Acheson, 1959; Park and Richter, 1953). They could be identified on various bones as vertebrae, ilium and patella (Abraham et al., 2001; Cunningham and Stephen, 2010; Edwards, 1993; Sajko et al., 2011) even if they are mostly analyzed on long-bones and alleged to be most frequently found on distal end of tibiae (Garn et al., 1968; Gindhart, 1969; Park and Richter, 1953). This higher frequency of HLs formed on the tibia is commonly explained through better blood circulation, an important concentration of osteoblasts and a greater sensitiveness to infections related to this bone (Hughes et al., 1996; Ortner, 2003; Park, 1964). The formation process of these transverse lines is widely well-known since the 1950s thanks to laboratory experimental studies on animals (Acheson, 1959; Alfonso-Durruty, 2011; Park and Richter, 1953). They represent a disturbance of the growth plate activity characterized by a reduced proliferation of chondrocytes, an extensive abnormal calcification and an unusual horizontally orientation in the deposition of osteoblasts. HLs can be formed during the growth process of an individual, in the metaphysis of the long bones, until the definitive growth plate closure. HLs are likely to be produced after stress episodes that generate a slowing down or an arrest of growth but some authors consider that for an effective HL formation the arrest of growth has to be complete and followed by a sufficient recovery (Acheson, 1959; Park, 1964; Park and Richter, 1953).

Following the first works of H.A. Harris, several clinical studies were conducted on contemporary population to detect the etiology of HLs. Various factors were identified such as specific diseases like rickets, osteoporosis, malaria, children's illnesses and respiratory ones, 
e.g. pneumonia, measles, chickenpox, whooping cough (Acheson, 1959; Arnay-de-la-Rosa et al., 1994; Garn et al., 1968; Gindhart, 1969; Harris, 1931; Park and Richter, 1953). Malnutrition and vitamin or protein deficiencies were also incriminated (Acheson, 1959; Blanco et al., 1974; Dreizen et al., 1964; Harris, 1931; Himes, 1978). Others authors found that HLs presence was linked to alcohol consumption (Gonzalez-Reimers et al., 2007); immobilization and fractures (Abraham et al., 2001; Sajko et al., 2011; Yao and Seeger, 1997); or psychological stress (Khadilkar et al., 1998; Teele, 1999). The association between HLs and systemic conditions such as illnesses and malnutrition was widely examined and recognized whereas local factors such as fracture were alleged to be less prone to cause HLs formation (Garn et al., 1968; Hughes et al., 1996; Park, 1964).

The co-occurrence between HLs and deficient conditions led anthropologists to use HLs as an indicator to reconstruct health and nutritional status of past populations. These palaeopathological studies started to be conducted by North-American anthropologists (Buikstra, 1976; Goodman and Clark, 1981; McHenry, 1968) and were, in parallel, developed in Europe (Hughes et al., 1996; Mays, 1995; Papageorgopoulou et al., 2011; Piontek et al., 2001; Ribot and Roberts, 1996). However, some authors have recently questioned this etiology and the status of HLs as an arrested growth indicator. Indeed, HLs could be visible on unhealthy children but also on healthy ones (Dreizen et al., 1964; Gindhart, 1969). Their co-occurrence with other stress indicators, i.e. linear enamel hypoplasia, was not proven conclusively as some authors found it (Clarke, 1982) and others did not (Alfonso et al., 2005; Mays, 1995; McHenry, 1968; Ribot and Roberts, 1996). Last but not least, HLs were rarely correlated to altered stature and shorter metrical parameters (Mays, 1995; Papageorgopoulou et al., 2011; Piontek et al., 2001; Ribot and Roberts, 1996).

Some authors have suggested that all these paradoxical points could be explained by a more physiological thesis (Alfonso et al., 2005; Alfonso-Durruty, 2011; Chaumoître, 2007; Gilde, 2013; Papageorgopoulou et al., 2011). They have interpreted HLs as a result of normal saltatory growth process characterized by stasis and spurts. They have argued that HLs could be formed during accelerated growth, caused by hormonal secretions, without being associated with a stress episode.

In order to discuss the reliability of HLs as arrested growth indicator, we analyzed the relationship between HLs and metrical parameters within an archaeological sample composed of both subadults and adults. The aims were to test the potential incidence of HLs on length and shape of long bones and to interrogate their pattern of occurrence as concerns their age-atformation. 


\section{Material \& Methods}

The analysis was conducted on the skeletal material collected from the Maria Troon convent cemetery, situated in Dendermonde, Belgium. Historical sources indicated that the cemetery was created during a plague epidemic that raged in the city between 1579 and 1584. Among the epidemic victims, at least 120 individuals were alleged to be buried there. Plague is an infectious disease caused by the bacterium Yersinia pestis. It is formerly a disease of various rodent species, but it can be transmitted to human through animals' fleas. Throughout history, it causes at least three pandemics: Justinian plague (from $6^{\text {th }}$ to $8^{\text {th }}$ century), the Black Death (from $14^{\text {th }}$ century onwards), and the modern or Hong Kong plague (from $19^{\text {th }}$ to $20^{\text {th }}$ century). In the post-medieval period, recurrent plague outbreaks occurred in Europe, including Belgium. At Dendermonde, 99 individuals were excavated (table 1) and the hypothesis of a plague epidemic origin was strongly supported by the consistency between the dates given by the historical sources and the radiocarbon dating (end of the $16^{\text {th }}$ century and the early beginning of the $17^{\text {th }}$ century), by archaeological evidence, i.e. the recovery of several mass graves (simultaneous deposition) and by the highlighting of paleodemographical anomalies found to be similar to the ones identified in other plague cemeteries (Margerison and Knüsel, 2002; Castex, 2008; Castex and Kacki, in press). In this context, a paleopathological analysis of this population became important to develop as the short time between burials indicates that these individuals lived at the same period under similar living conditions.

Table 1. Age and sex distribution of individuals from Dendermonde collection.

\begin{tabular}{lcccc}
\hline Age-group & \multicolumn{3}{c}{ Sex } & Total \\
\cline { 2 - 4 } & Females & Males & Indeterminable & \\
\hline 1-4 years & 0 & 0 & 5 & 5 \\
5-9 years & 0 & 0 & 11 & 11 \\
5-9 / 10-14 years & 0 & 0 & 12 & 12 \\
10-14 years & 0 & 0 & 17 & 17 \\
10-14 / 15-19 years & 0 & 0 & 5 & 5 \\
15-19 years & 2 & 0 & 6 & 8 \\
20-29 years & 8 & 8 & 3 & 19 \\
30+ years & 9 & 10 & 3 & 22 \\
Total & 19 & 18 & 62 & 99 \\
\hline
\end{tabular}


Of the 99 skeletons recovered during the excavation, 69 were well preserved enough to search for HLs, including 28 adults and 41 subadults (table 2). The sex of adult individuals was determined using morphological characteristics of os coxae (Bruzek, 2002; Murail et al., 2005). The age-at-death was estimated using several methods. For the subadults, we focused on the degree of mineralization of the teeth (Moorrees et al., 1963). When they were absent, the estimation was based on the length of long bones (Maresh, 1970) and the degree of epiphyseal fusion (Coqueugniot and Weaver, 2007). The adequacy between the age estimation based on dental mineralization and bone length was tested by applying a Wilcoxon T-test. No differences were highlighted ( $p>0.05)$, so that we decided to use both methods for age estimation.

Within the adult group, the younger adults (aged between 20 and 29 years old) were distinguished from the older ones (aged 30 years old and above) using the quotation of the latest ossification points (Owings-Webb and Suchey, 1985).

Table 2. Age and sex distribution of radiographed individuals from Dendermonde collection.

\begin{tabular}{|c|c|c|c|c|}
\hline \multirow[t]{2}{*}{ Age-group } & \multicolumn{3}{|c|}{ Sex } & \multirow[t]{2}{*}{ Total } \\
\hline & Females & Males & Indeterminable & \\
\hline 1-4 years & 0 & 0 & 4 & 4 \\
\hline $5-9$ years & 0 & 0 & 8 & 8 \\
\hline 5-9 / 10-14 years & 0 & 0 & 7 & 7 \\
\hline $10-14$ years & 0 & 0 & 15 & 15 \\
\hline $15-19$ years & 2 & 0 & 5 & 7 \\
\hline Younger Adults & 7 & 5 & 0 & 12 \\
\hline Older Adults & 8 & 8 & 0 & 16 \\
\hline Total & 17 & 13 & 39 & 69 \\
\hline
\end{tabular}

Antero-posterior radiographs were carried out on each preserved femur and tibia. These bones were selected since they were among the best preserved in the collection and known to be the most likely to present HLs (Garn et al., 1968; Gindhart, 1969). We selected bones free of pathology (e.g. fracture, infection), entire bones or bones with at least one extremity, i.e. distal one for the femur, proximal and/or distal end for the tibia ( $n=102$ femoral ends, $n=182$ tibial ends). Radiographs were performed at the Royal Museum of Central Africa (Tervuren, Belgium) using a machine prototype (Visix) designed by two Belgian companies (Medex Loncin SA and Xris). The radiographs parameters applied were as following: 50-60 kV, 2000mA, 30 seconds exposure time and $1.6 \mathrm{~m}$ distance. Radiographs were saved as PNG files and the image processing was executed using Maestro ${ }^{\odot}$ software. 
The rating of HLs was performed by naked-eye by one of the authors (AB) following criteria defined by Goodman and Clark (1981), registering a HL as any transverse line which extended at least one quarter across the bone width (figure 1). We registered the presence or absence of the indicator and specified the number of HLs observed at each extremity. Intra-observers errors were assessed by calculating a Cohen’s Kappa coefficient (Cohen, 1960).

From this rating process, we developed an individual scale analysis by considering the maximal number of HLs observed at one extremity, femur or tibia, as the minimal number of stress episodes an individual had suffered during his life. Subsequently, we defined three groups: group 0 was composed of individuals with no HL, group 1 grouped individuals whose bones have recorded one or two stress episodes, and group 2 represented the most stressed individuals, with more than two stress episodes recorded on bone.

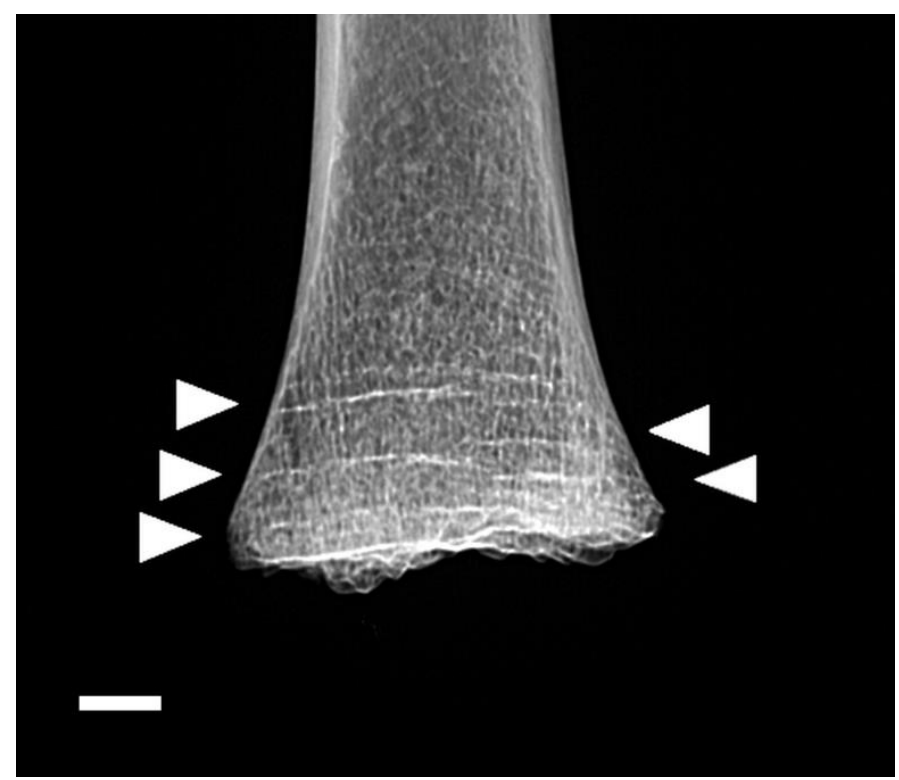

Figure 1. Example of Harris lines, indicated by arrows, on the distal end of a right tibia (Dendermonde, skeleton 14, 5-9 year old), Scale: $1 \mathrm{~cm}$.

Comparisons of HLs prevalence between and within subadult and adult groups were performed using chi-square test. When sample sizes were small and expected cell frequencies less than five, we used Fisher's exact test instead.

Age-at-formation of each detected HL was calculated using Hummert and Van Gerven's method (Hummert and Van Gerven, 1985). It allowed developing an analysis of the growth within the population, without comparing it to exterior modern growth data (Hunt and Hatch, 1981; Clarke, 1982; Maat, 1984; Byers, 1991). This method is based on the restitution of the ossification center, considering that both extremities of long bone do not grow at the same rate 
- e.g. $43 \%$ of growth of tibia occurs at the distal portion whereas it is $71 \%$ for the distal part of femur (Anderson et al., 1963). To determine the age of each HL at the time of its deposition, the distance between the ossification center and the HL was measured, directly on radiographs, using Adobe Photoshop ${ }^{\odot}$ software. Since we decided to work on age groups, we defined the growth pattern of the population for each group by considering the variation of lengths (minima and maxima) within the age range to reliably calculate the age-at-formation of HLs.

In order to investigate the relationship between HLs and growth, bone measurements were taken on both left and right elements (table 3). The cortical thickness of both femur and tibia were obtained from the radiographs, through calculation of the cortical index (CI) (Dequeker, 1976; Mays, 1995):

$$
\mathrm{CI}=\frac{\text { total bone width }- \text { medullary width }}{\text { total bone width }} \times 100
$$

Table 3. List of bone measurements taken on femora and tibiae of Dendermonde collection, from Brauer, 1988.

\begin{tabular}{lll}
\hline Bone & Measurement & $\begin{array}{l}\text { Abbreviations } \\
\text { (from Brauer, 1988) }\end{array}$ \\
\hline Femur & Maximal length & M1 \\
& Anterior-posterior subtrochanteric diameter & M10 \\
& Medial-lateral subtrochanteric diameter & M9 \\
& Anterior-posterior midshaft diameter & M6 \\
& Medial-lateral midshaft diameter & M7 \\
& Midshaft circumference & M8 \\
& Epicondylar breadth & M21 \\
\hline Tibia & Maximum length & M1 \\
& Anterior-posterior diameter at nutrient foramen & M8a \\
& Medial-lateral diameter at the nutrient foramen & M9a \\
& Circumference at the nutrient foramen & M10b \\
& Maximal proximal epiphyseal breadth & M3 \\
& Maximal distal epiphyseal breadth & M6 \\
\hline
\end{tabular}

HLs rating data were then coupled to these collected metrical parameters through a statistical analysis. The three defined groups were investigated to detect the influence of the presence and the number of HLs on metrical parameters. We tested the metrical differences between the individuals without HLs (group 0) and the individuals with HLs (groups 1 and 2); and between the individuals with few HLs (groups 0 and 1) and the individuals with many HLs (group 2). We performed an ANOVA analysis and constructed boxplots for each metrical parameter. 
These statistical tests were separately carried out within the subadult and adult group. Within the adult group, the sex variable was taken into account.

All statistical analyses were performed in $\mathrm{R}^{\odot}$, version 3.0.2, with a p-value significance threshold of 0.05 .

\section{Results}

The examination of 102 femoral extremities and 181 tibial ends revealed the presence of 159 HLs, which concerns 73 bony ends. HLs were present in 36 of 69 individuals (52\%), including 24 subadults (59\%) and 12 adults (43\%). Although individuals younger than 20 years-old were more commonly affected than their older counterparts, the difference was not statistically significant $\left(\chi^{2}=1.64, \mathrm{df}=1, \mathrm{p}=0.20\right)$. Within the subadult group, most of the individuals below 10 years showed at least one HL, whereas these features were statistically less common in older subadults (Fisher's exact test; p<0.01). Within the adult group, HLs prevalence was slightly higher in younger adults, but the difference with older adults was not significant $\left(\chi^{2}=0.44, \mathrm{df}=1\right.$, $\mathrm{p}=0.51$ ). The overall prevalence and the prevalence for femur and tibia in each age group are presented in table 4.

Table 4. Prevalence of HLs per age groups and per bones (femora and tibiae) within Dendermonde collection.

\begin{tabular}{c|c|c|c|c|c|c|c} 
& \multicolumn{7}{c}{ Age groups } \\
\cline { 2 - 8 } & $\begin{array}{c}1-4 \\
\text { years }\end{array}$ & $\begin{array}{c}5-9 \\
\text { years }\end{array}$ & $\begin{array}{c}5-9 / 10- \\
14 \text { years }\end{array}$ & $\begin{array}{c}10-14 \\
\text { years }\end{array}$ & $\begin{array}{c}15-19 \\
\text { years }\end{array}$ & $\begin{array}{c}\text { Younger } \\
\text { Adults }\end{array}$ & $\begin{array}{c}\text { Older } \\
\text { Adults }\end{array}$ \\
\hline $\mathrm{n}$ & 4 & 8 & 7 & 15 & 7 & 12 & 16 \\
\hline $\begin{array}{c}\text { Individuals } \\
\text { with HLs } \\
\text { (both bones } \\
\text { considered) }\end{array}$ & $100 \%$ & $88 \%$ & $57 \%$ & $40 \%$ & $43 \%$ & $50 \%$ & $38 \%$ \\
\hline $\begin{array}{c}\text { Femora with } \\
\text { HLs }\end{array}$ & $100 \%$ & $63 \%$ & $0 \%$ & $0 \%$ & $0 \%$ & $16 \%$ & $6 \%$ \\
\hline $\begin{array}{c}\text { Tibiae with } \\
\text { HLs }\end{array}$ & $75 \%$ & $88 \%$ & $57 \%$ & $40 \%$ & $43 \%$ & $34 \%$ & $32 \%$ \\
\hline
\end{tabular}

When we classified the individuals into groups (group 0, group 1 and group 2) according to the number of HLs they display, the distal end of tibia, if preserved, constantly showed the highest number of HLs, at least equally or more than the others extremities. For the 14 individuals that 
did not have preserved distal end of tibia, the classification was based on HL rating from another bone, from the proximal end of tibia for 5 cases, and from the distal femur for 9 cases. When these other ends were used, the individuals were classified into the group 0 ( 4 cases out of 33), the group 1 ( 6 cases out of 20) and into the group 2 (4 cases out of 16). This balanced division suggests that the use of another extremity did not entail a methodological bias and did not systematically put the individuals in the less stressed group.

Table 5. Classification of individuals into 3 groups according to the number of HLs rated, Group 0: no HL, Group 1: HLs indicative of one or two stress episodes, Group 2: HLs indicative of more than 2 stress episodes, within Dendermonde collection.

\begin{tabular}{cccc}
\cline { 2 - 4 } & Group 0 & Group 1 & Group 2 \\
\hline Subadults & 17 & 14 & 10 \\
Adults & 16 & 6 & 6 \\
Total & 33 & 20 & 16 \\
\hline
\end{tabular}

The Cohen's Kappa coefficients obtained by confronting two series of HLs rating from the observer are satisfactory in average (table 6). It confirmed the reproducibility of the observations and justified the robustness of the analysis performed on HLs prevalence.

Table 6. Intra observer errors (Cohen's Kappa coefficient) calculated for Harris Lines rating (presence and number) by anatomical region for two series of observations, in italic: satisfactory agreement (0.61-0.80), in bold: excellent agreement (0.81-1.00), from Landis and Loch (1977).

\begin{tabular}{|c|c|c|c|c|c|c|}
\hline & \multicolumn{2}{|c|}{ Distal femur } & \multicolumn{2}{|c|}{ Proximal tibia } & \multicolumn{2}{|c|}{ Distal tibia } \\
\hline & Presence & Number & Presence & Number & Presence & Number \\
\hline Right & 0.767 & 0.798 & 0.948 & 0.687 & 0.491 & 0.888 \\
\hline Left & 0.657 & 0.618 & 0.827 & 0.664 & 0.657 & 0.647 \\
\hline
\end{tabular}

Age-at-formation could only be assessed for entire bones. On the 159 recorded HLs, we could calculate this age for 145, i.e 91\% of observed HLs (table 7). The peak of HLs formation for subadults was between 5 and 9 years old. Within the adult group, the majority of HLs belonging to younger adults and older ones (50\% to 58\%) were formed between 10 and 14 years old. Only one out of $13 \mathrm{HL}$ formed around one year old was belonging to an adult individual. Age-atformation was calculated for $13 \mathrm{HLs}$ belonged to females and $26 \mathrm{HLs}$ belonged to males (table 8). For females, the majority of lines were formed between 10 and 14 years old. For males, the same amount of HLs were formed between 5 and 9 years and between 10 and 14 years old 
Table 7. Distribution of age-at-formation of HLs by age group within Dendermonde collection.

\begin{tabular}{|c|c|c|c|c|c|c|c|c|}
\cline { 2 - 9 } \multicolumn{1}{c|}{} & \multicolumn{7}{c|}{ Age group } \\
\hline $\begin{array}{c}\text { Age-at- } \\
\text { formation }\end{array}$ & $\mathrm{n}$ & $\begin{array}{c}1-4 \\
\text { years }\end{array}$ & $\begin{array}{c}5-9 \\
\text { years }\end{array}$ & $\begin{array}{c}5-9 / 10-14 \\
\text { years }\end{array}$ & $\begin{array}{c}10-14 \\
\text { years }\end{array}$ & $\begin{array}{c}15-19 \\
\text { years }\end{array}$ & $\begin{array}{c}\text { Younger } \\
\text { Adults }\end{array}$ & $\begin{array}{c}\text { Older } \\
\text { Adults }\end{array}$ \\
\hline $\mathrm{HL}<4$ years & 20 & 9 & 7 & 0 & 0 & 3 & 1 & 0 \\
\hline HL 5-9 years & 97 & & 47 & 14 & 10 & 10 & 8 & 8 \\
\hline HL 10-14 years & 28 & & & 0 & 6 & 0 & 10 & 12 \\
\hline
\end{tabular}

Table 8. Distribution of age-at-formation of HLs by age group for sexed individuals, within Dendermonde collection.

\begin{tabular}{|c|c|c|c|c|}
\cline { 2 - 5 } \multicolumn{1}{c|}{} & \multicolumn{4}{c|}{ Sexed individuals } \\
\cline { 2 - 5 } \multicolumn{1}{c|}{} & \multicolumn{2}{c|}{ Younger adults } & \multicolumn{2}{c|}{ Older adults } \\
\hline $\begin{array}{c}\text { Age-at- } \\
\text { formation }\end{array}$ & Female & Male & Female & Male \\
\hline $\mathrm{HL}<4$ years & 1 & 0 & 0 & 0 \\
\hline $\mathrm{HL} \mathrm{5-9}$ years & 2 & 6 & 1 & 7 \\
\hline $\mathrm{HL} 10-14$ years & 3 & 7 & 6 & 6 \\
\hline
\end{tabular}

Comparison of bones size and shape between individuals with and without HLs could only be performed for two subadult age groups: [5-9] and [10-14] age groups. We excluded individuals upon these two age groups because it would not have been relevant to compare metrical parameters of individuals whose age could differ more than 5 years. It was also not possible to carry out statistical tests on the [1-4] and [15-19] age groups as the headcount between individual with and without HLs was not balanced and the amount of collected measurements not sufficient. On the contrary, the whole adult sample was investigated by distinguishing younger and older adults.

\section{Subadult sample}

The results of the ANOVA analysis revealed that the occurrence of HLs did not affect maximal femoral and tibial lengths for both sides (p-values $>0.1, \mathrm{~S}$-tables 1 and 2) within the subadult group.

However, significant differences were found when investigating shape parameters. Between the individuals without HLs and with HLs, five metrical parameters were impacted. Within the [59] age group, differences affected the antero-posterior sub-trochanteric diameter of the left femur, the distal breath of left femur and the proximal breadth of right tibia $(\mathrm{p}<0.05$, S-table 1$)$. Within the [10-14] age group, values of the antero-posterior diameter at nutrient foramen of left 
tibia and circumference of right tibia were significantly different $(\mathrm{p}<0.05$, S-table 1$)$. Besides, differences in shape parameters between the individuals with few HLs and those with many HLs were also highlighted only within the [5-9] age group: three femoral shape parameters and three tibial shape parameters $(\mathrm{p}<0.05$, S-table 2$)$.

For all of these metrical parameters, boxplots demonstrated that subadults with the more HLs showed constantly slighter measurements than subadults with no or less HLs (figures 2 and 3).

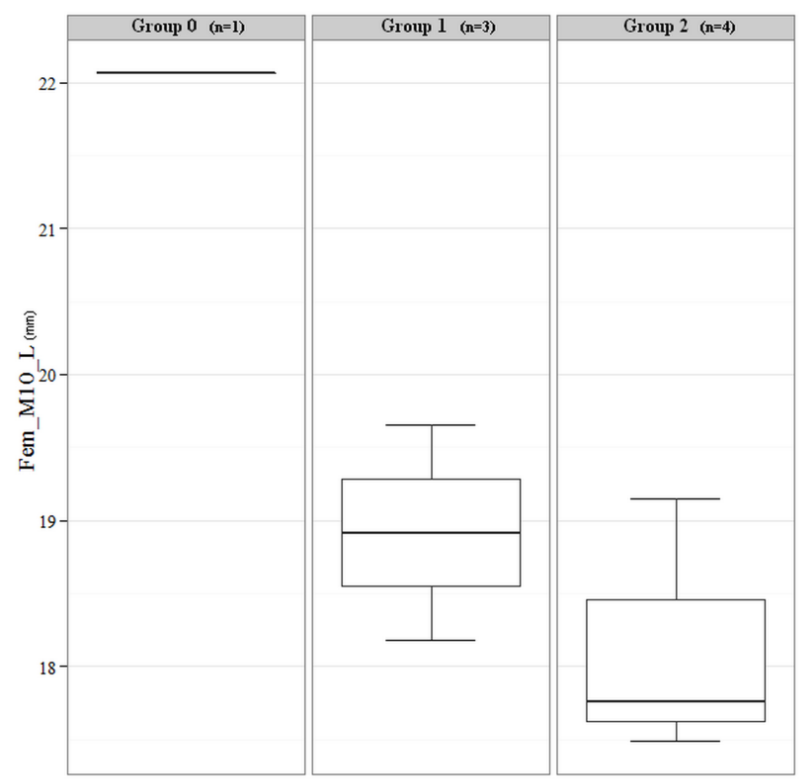

Figure 2. Box-plot showing metrical differences between the three groups of individuals by HLs presence, anterior-posterior subtrochanteric diameter (left femur, [5-9] age group).

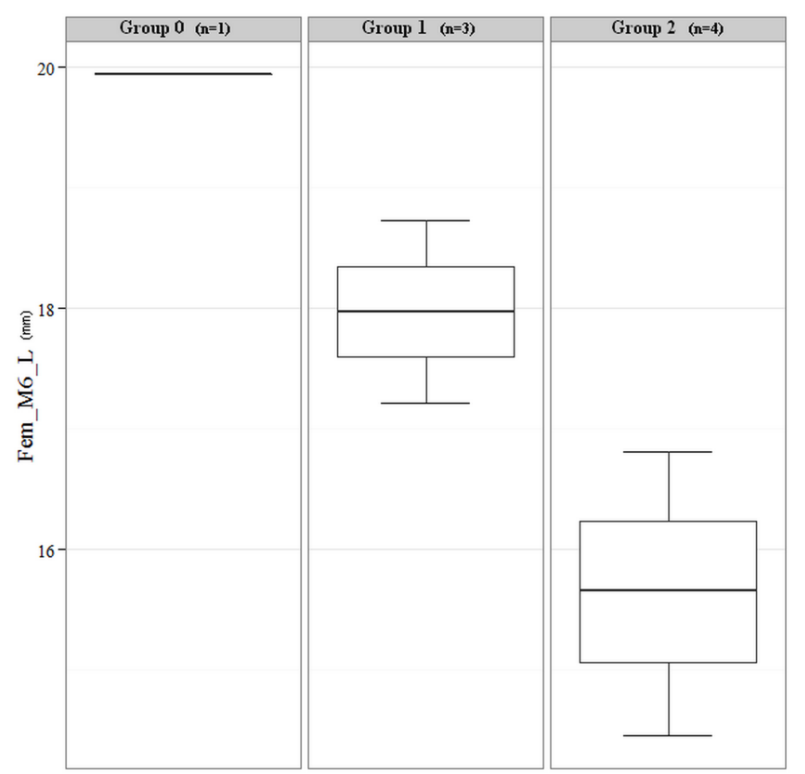

Figure 3. Box-plot showing metrical differences between the three groups of individuals by HLs presence, anterior-posterior diameter at midshaft (left femur, [5-9] age group). 


\section{Adult sample}

When considering adult individuals, the results of the ANOVA analysis revealed that the occurrence of HLs did not affect maximal femoral and tibial lengths for both sides (pvalues $>0.1$, S-tables 3 and 4 ). When the p-values were found to be significant, they were linked to shape measurements.

Within the younger adults, between the individuals without HLs and with HLs, eight parameters were significantly different, all related to shape parameter $(\mathrm{p}<0.05$, S-table 3$)$. Five femoral shape parameters and two tibial shape parameters were significantly distinct between the individuals with few HLs and with many HLs ( $\mathrm{p}<0.05$, S-table 4).

The constructed boxplots demonstrated that the males with HLs showed constantly larger measurements than the males without HLs. In contrast, females with HLs often displayed slighter measurements than females without HLs (figures 4 and 5).

Within the older adult group, no significant difference was found (S-tables 3 and 4).

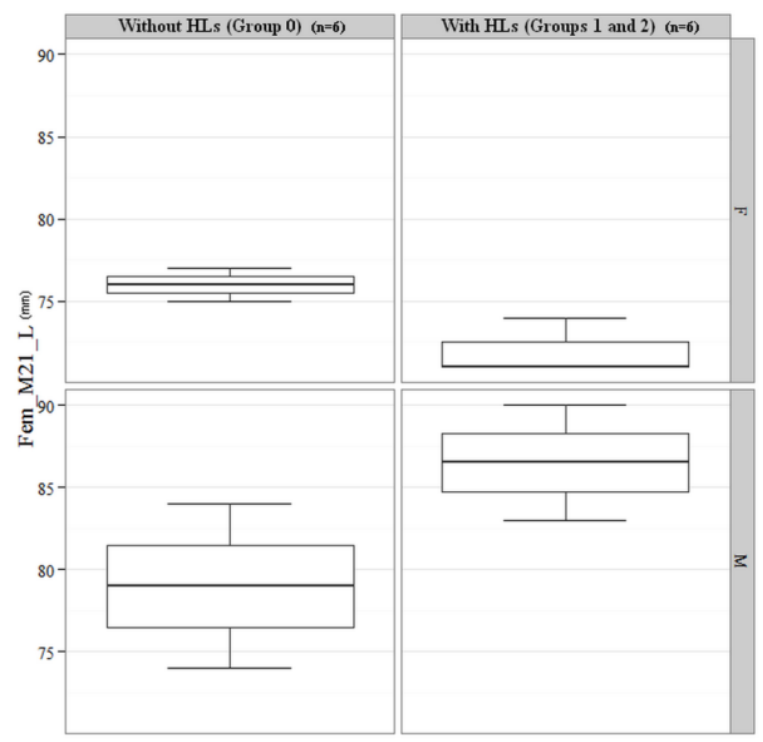

Figure 4. Box-plot showing metrical differences between the younger adults without HLs and with HLs by sex group, femoral distal breadth (left femur, younger adults). 


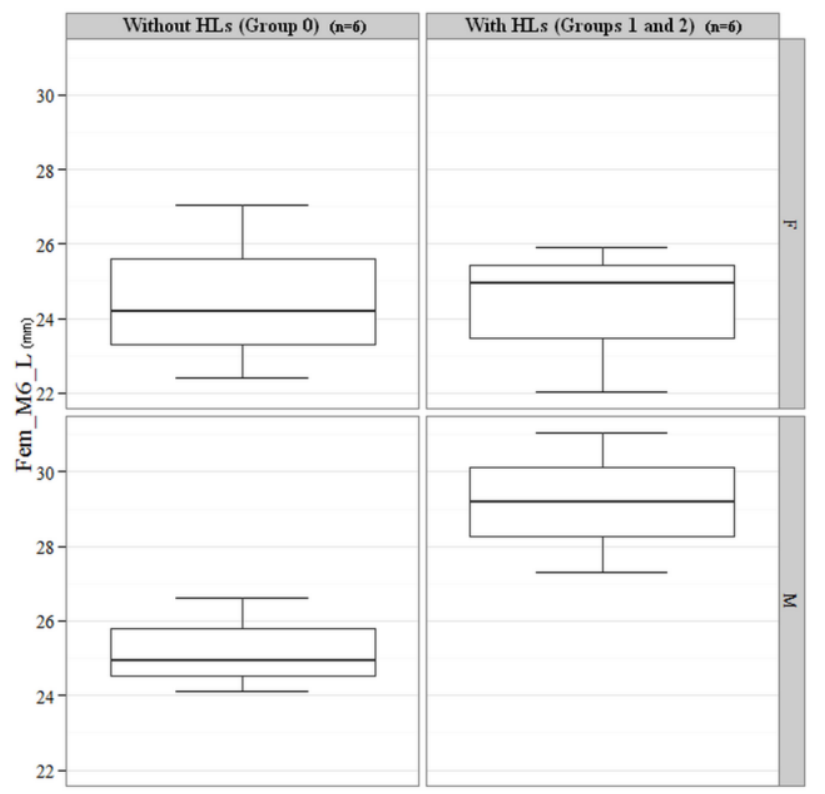

Figure 5. Box-plot showing metrical differences between the younger adults without HLs and with HLs by sex group, anteroposterior midshaft femoral diameter (left femur, younger adults).

\section{Discussion}

\section{Prevalence}

An average prevalence of HLs was found in the post-medieval osteological collection of Dendermonde. Only half of the individuals showed at least one HL on the femur or tibia. The HLs prevalence at Dendermonde is part of the variability observed for this indicator in both plague and attritional cemeteries (table 9).

The prevalence of HLs between the subadult and the adult groups was not statistically different. Similar results were found in both plague and attritional cemeteries (Chaumoître, 2007; Mays, 1995; Nowak and Piontek, 2011; Papageorgopoulou et al., 2011). Within the subadult sample, the younger ones showed statistically more HLs than the other ones. It may be either due to the fact that the younger subadults were more affected to stress episodes due to their inner frailty (Saunders and Hoppa, 1993) or to the disappearance of some lines on older subadults due to active remodeling process (Grolleau-Raoux et al., 1997). Similarly, within the adult sample, more HLs were recorded on the younger individuals, although the statistical difference was not significant. The same trend was previously observed in two attritional cemeteries (Gilde, 2013; Beom et al., 2014). This decrease of HLs prevalence is consistent with a more prolonged remodeling process on older individuals due to their age-at-death. 
Table 9. HLs prevalence for all age groups observed in plague and attritional cemeteries from medieval and modern periods.

\begin{tabular}{|c|c|c|c|c|c|c|c|}
\hline & Site & Location & Dates & $\begin{array}{l}\text { Identification - HLs } \\
\text { criteria }\end{array}$ & $\begin{array}{c}\text { Sample } \\
\text { Size } \\
\text { (all age } \\
\text { groups) }\end{array}$ & $\begin{array}{c}\text { HLs } \\
\text { prevalence }\end{array}$ & References \\
\hline \multirow{4}{*}{$\begin{array}{c}\text { Plague } \\
\text { Cemeteries }\end{array}$} & $\begin{array}{c}\text { Maria Troon } \\
\text { Dendermonde }\end{array}$ & $\begin{array}{c}\text { Dendermonde } \\
\text { Belgium }\end{array}$ & $\begin{array}{c}1579-1584 \\
\text { AD }\end{array}$ & $\begin{array}{l}\geq 25 \% \text { diaphysis } \\
\text { width }\end{array}$ & 69 & $52 \%$ & Present study \\
\hline & Les Fédons & $\begin{array}{l}\text { Lambesc } \\
\text { France }\end{array}$ & $1590 \mathrm{AD}$ & $\begin{array}{c}\geq 30 \% \text { diaphysis } \\
\text { width }\end{array}$ & 38 & $29 \%$ & Fiscella, 2007 \\
\hline & Vodroffsgaard & $\begin{array}{c}\text { Copenhagen } \\
\text { Denmark }\end{array}$ & $\begin{array}{c}1711-1712 \\
A D\end{array}$ & $\begin{array}{l}\geq 30 \% \text { diaphysis } \\
\text { width }\end{array}$ & 24 & $12 \%$ & Fiscella et al., 2008 \\
\hline & $\begin{array}{l}\text { Observance } \\
\text { and Delos }\end{array}$ & $\begin{array}{l}\text { Marseille } \\
\text { France }\end{array}$ & $\begin{array}{c}1720-1722 \\
A D\end{array}$ & $\begin{array}{l}\geq 25 \% \text { diaphysis } \\
\text { width }\end{array}$ & 113 & $64 \%$ & Chaumoître, 2007 \\
\hline \multirow{7}{*}{$\begin{array}{l}\text { Attritional } \\
\text { cemeteries }\end{array}$} & Kulubnarti & $\begin{array}{l}\text { Soudan } \\
\text { Nubia }\end{array}$ & $\begin{array}{l}6-15^{\text {th }} \\
\text { century }\end{array}$ & $\begin{array}{l}\geq 50 \% \text { diaphysis } \\
\text { width }\end{array}$ & 324 & $76 \%$ & $\begin{array}{c}\text { Hummert and Van } \\
\text { Gerven, } 1985\end{array}$ \\
\hline & $\begin{array}{c}\text { Unterseen and } \\
\text { Oberbueren }\end{array}$ & $\begin{array}{l}\text { Bern Canton } \\
\text { Switzerland }\end{array}$ & $\begin{array}{l}7-15^{\text {th }} \\
\text { century }\end{array}$ & $\begin{array}{l}\geq 25 \% \text { diaphysis } \\
\text { width }\end{array}$ & 112 & $78 \%$ & Ameen et al., 2005 \\
\hline & Cedynia & Poland & $\begin{array}{l}10-14^{\text {th }} \\
\text { century }\end{array}$ & $\begin{array}{l}\geq 25 \% \text { diaphysis } \\
\text { width }\end{array}$ & 324 & $74 \%$ & Piontek et al., 2001 \\
\hline & Tomils & $\begin{array}{l}\text { Bern Canton } \\
\text { Switzerland }\end{array}$ & $\begin{array}{l}11-15^{\text {th }} \\
\text { century }\end{array}$ & $\begin{array}{c}\geq 30 \% \text { diaphysis } \\
\text { width }\end{array}$ & 241 & $77 \%$ & $\begin{array}{c}\text { Papageorgopoulou } \\
\text { et al., } 2011\end{array}$ \\
\hline & $\begin{array}{c}\text { Waterford and } \\
\text { Tintern }\end{array}$ & Irland & $\begin{array}{l}11-17^{\text {th }} \\
\text { century }\end{array}$ & $\begin{array}{l}\geq 25 \% \text { diaphysis } \\
\text { width }\end{array}$ & 73 & $36 \%$ & Hughes et al., 1996 \\
\hline & Saint- Maurice & $\begin{array}{c}\text { Val de Marne } \\
\text { France }\end{array}$ & $\begin{array}{c}17^{\text {th }} \\
\text { century }\end{array}$ & $\begin{array}{l}\geq 25 \% \text { diaphysis } \\
\text { width }\end{array}$ & 65 & $20 \%$ & $\begin{array}{l}\text { Hadjouis and Amar, } \\
2009\end{array}$ \\
\hline & $\begin{array}{c}\text { Wharram } \\
\text { Percy }\end{array}$ & $\begin{array}{c}\text { Yorkshire } \\
\text { UK }\end{array}$ & $\begin{array}{l}10-19^{\text {th }} \\
\text { century }\end{array}$ & $\begin{array}{l}\geq 50 \% \text { diaphysis } \\
\text { width }\end{array}$ & 288 & $28 \%$ & Mays, 1995 \\
\hline
\end{tabular}

Age-at-formation

At Dendermonde, the HLs age-at-formation distribution was different between the subadult and the adult group. Most of the subadults HLs were formed between 5 and 9 years old. This formation peak fits with observations made in previous archaeological studies where HLs were formed between 4 and 7 years (Hummert and Van Gerven, 1985; Chaumoître, 2007; Papageorgopoulou, 2011). However, a formation peak around 2 and 3 year, not found here, was highlighted by clinical studies (Dreizen et al., 1964; Gindhart, 1969). On the contrary, most of the HLs observed on adults were formed between 10 and 14 years, as found in previous studies (Ameen et al., 2005; Piontek et al. 2011; Papageorgopoulou, 2011). Only one HL was formed before the end of an individual first year. This latter observation could be interpreted as a consequence of the remodeling process. Indeed, in adulthood, the oldest HLs are likely to be resorbed whereas HLs formed during the latest stresses are likely to be still visible (Hughes et al., 1996; Hummert and Van Gerven, 1985; Lewis and Roberts, 1997). However, it is noteworthy that none of the HLs recorded in the Dendermonde sample were formed between 
15 and 19 years, i.e. the last period of bone growth. So, the remodeling process is not the only factor to explain the age-at-formation distribution. There is a significant span of HLs formation between 10 and 14 years.

\section{HLs: a marker of arrested growth?}

HLs have been associated to deficient health conditions since the initial work of H.A. Harris in 1931. They are commonly considered to be subsequent to pathological factors (illnesses, infections, nutritional deficiencies) which abnormally slow and arrest bone growth. In the present study, a systematic confrontation of HLs rating data and metrical parameters of the individuals was performed in order to discuss the reliability of this pathological thesis. We took as a widely accepted assumption that if HLs were the result of arrested growth, the most HLs an individual had the most altered would be his growth and the shortest would be his metrical parameters. HLs would be associated with a negative impact on the growth pattern. The defined groups of individuals were confronted to test both influence of the presence and the number of HLs on the bone measurements. The main asset of the narrow chronology of the Dendermonde collection was to provide a snapshot of a population living at the same period under similar living conditions. Therefore, the results obtained from ANOVA analysis on metrical parameters were not influenced by secular variations, unlike previous studies (e.g. Mays, 1995; Nowak and Piontek, 2002 and 2011; Papageorgopoulou et al., 2011; Ribot and Roberts, 1996).

Within the subadult group, we demonstrated that the presence of HLs had no significant impact on the size of individuals. The absence of correlation between HLs and stature matches previous archeological studies (Mays, 1995; Papageorgopoulou et al., 2011). Even combined with other stress indicators (linear enamel hypoplasia, cribra orbitalia, periostitis) Ribot and Roberts (1996) did not find significant differences between individuals with and without HLs, as regards maximal length of humerus, femur and tibia.

However, our results show that several shape parameters were negatively affected by the presence of HLs. Subadults with HLs displayed constantly slighter shape measurements than individuals without HLs. These findings are consistent with Mays' observations at Wharram Percy on femoral cortical index (Mays, 1995). The investigation on other shape parameters has not been done prior to this study.

The difference of impact between size and shape parameters can be explained by the fact that catch-up following growth arrest occurs preferentially for bone length rather than bone width (Garn et al., 1968; Himes, 1978; Mays, 1995). Additionally, the correlation between HLs presence and shorter measurements for some shape parameters seems to indicate that the growth 
of the individual has been disturbed by a temporary arrest. Pathological and unfavorable socioeconomic conditions are likely to be at the origin of this arrest and to be the underlying causes of the formation of most of the HLs in the subadult sample. But, we cannot exclude that these HLs could have formed after a normal physiological stasis preceding a spurt. Though, it remains complex to understand why this following spurt had not entailing a normal growth catch-up on the shape measurements.

Cautiousness is needed when looking at these results as several factors could limit the interpretation. Firstly, we had no access to the biological sex of the subadults as any existing methods was not reliable enough (Lewis, 2006; Sutter, 2003). By a sample bias, any subadult with HLs could have been a girl with commonly slighter metrical parameter (Tanner, 1960). Also, the age range of subadult groups was wide. Thereby, the subadults with HLs could have displayed shorter shape parameters because they were the youngest in the age range. The size of the subadult sample is above all limiting further interpretations.

Regarding the adult group, significant differences were obtained only for the younger adults. The absence of differences for the older adults could be the consequence of the remodeling process which obscures the relationship between HLs and metrical parameters (Lewis and Roberts, 1997; Mays, 1995). As observed in previous anthropological studies, no difference between individuals with and without HLs was found when investigating size parameters (Mays, 1995; Papageorgopoulou et al., 2011; Nowak and Piontek, 2011). The absence of impact of HLs on cortical index matches with Mays' study (Mays, 1995). At Dendermonde, the presence of HLs did affect only shape parameters, as femoral diameter, circumference and distal breath; and tibial diameter and circumference. Only one previous archaeological study deals with such measurements. Nowak and Piontek (2002) investigated the influence of HLs on bone form on the adult individuals of the Cedynia medieval cemetery (Poland). They found significant differences between individuals by the presence of the indicator for shape measurements on humerus, radius and tibia.

The impact of HLs on adult shape parameters was noted to be different by the sex. Males with HLs showed constantly larger shape parameters than individuals without HLs. A similar trend is observed within the Cedynia collection (Nowak and Piontek, 2002). However, for females the pattern was less clear, perhaps due to minor fluctuations.

In both subadult and adult samples, there are differences in some shape parameters between individuals with HLs and individuals without. The shape parameters concerned are similar for femur and tibia, i.e. antero-posterior diameters and shaft circumference. It appears that HLs have a significant impact on shape parameters regardless of the bone. The nature of the impact 
is, however, distinct between the two samples: negative in the subadult sample and positive in the adult one. The positive impact of HLs presence, especially on males shape parameters, seems obviously inconsistent to the main assumption considering HLs as a marker of arrested growth.

\section{New insights to identify HLs etiology}

Results obtained from ANOVA tests were contradictory, at Dendermonde, between the subadult and adult groups. Additionally, it is noteworthy that HLs observed in subadults and adults did not form at the same age: most of the HLs recorded in subadults were formed between 5 and 9 years whereas most of the HLs observed in their older counterparts were formed between 10 and 14 years.

The period between 5 and 9 years, corresponding to childhood, is recognized as a period of relatively stable and softened growth and sexual dimorphism (Rogol et al., 2002; Dattani and Preece, 2004). Growth stasis and spurts of physiological origin are reduced at these ages. Therefore, most of the HLs formed at this period, are likely to be linked to unfavorable conditions, pathological or socio-economic, which can occasion growth failures.

In contrast, the peak of HLs formation between 10 and 14 years fits with the puberty stage characterized by an increased growth velocity, under growth hormones and sexual steroids influence (Dattani and Preece, 2004). HLs formed between 10 and 14 years are likely to be the result of a normal saltatory growth (Lampl and Johnson, 1997) and to represent the hallmark of puberty: the adolescent growth spurt. It could explain why the males with HLs displayed larger parameters than males without HLs, at Dendermonde. The fact that the females did not follow the same pattern tends to indicate that their pubertal tempo growth is less irregular and intensive than the males' one (Gill et al., 2001; Rogol et al., 2002; Marceau et al., 2011).

But, growth is a less simple process in detail, and discordance exists between short-term and long-term growth patterns. While long-term growth seems linear, especially during the midchildhood, from a short-term point of view this period can be rhythmed by diurnal and seasonal growth variations, alternating stasis and spurts (Butler et al., 1990; Gelander et al., 1994; Thalange et al., 1996). Growth velocity is also known to reach a nadir, called preadolescent dip, when approaching the puberty (Rogol et al., 2002). Due to this complexity, we cannot exclude the possibility that some HLs formed between 5 and 9 years represent physiological spurts or stasis, even though it seems unlikely that such short-term fluctuations can alter metrical parameters on long-term, as they did on Dendermonde subadult individuals.

If we compare age-at-formation distribution at Dendermonde with larger archaeological studies, it appears that similar results have been previously found (table 10). HLs observed on 
subadult individuals are frequently formed around two age peaks, 0-2 years and 5-11 years. They are interpreted as a result of various causes: weaning period for the earliest ones, childhood stresses linked to poor health and living conditions or vulnerability associated with prepubertal growth spurts for the latest ones. At Dendermonde, the latter factors are likely to cause the HLs formed between 5 and 9 years, in subadults. Regarding adult individuals, HLs are often formed during the pubertal period, i.e. 10-16 years, and formed earlier on females. They are constantly interpreted as reflecting the adolescent growth spurt. HLs visible on Dendermonde adult individuals are therefore likely to represent physiological events. However, it needs to be bore in mind that such comparisons between archaeological sites are in some extent skewed because of existing interpopulation variations.

Table 10. HLs age-at-formation distribution observed in cemeteries from medieval and modern periods.

\begin{tabular}{|c|c|c|c|c|c|c|c|c|}
\hline \multirow{2}{*}{ Site } & \multirow{2}{*}{ Dates } & \multirow{2}{*}{$\begin{array}{c}\text { Sample } \\
\text { size }\end{array}$} & \multirow{2}{*}{$\begin{array}{c}\text { HLs } \\
\text { prevalence }\end{array}$} & \multicolumn{2}{|c|}{ HLs age-at-formation } & \multicolumn{2}{|c|}{ Interpretations } & \multirow{2}{*}{ References } \\
\hline & & & & Subadults & Adults & Subadults & Adults & \\
\hline $\begin{array}{l}\text { Maria Troon } \\
\text { Dendermonde } \\
\text { (Belgium) }\end{array}$ & $\begin{array}{l}1579- \\
1584 \\
A D\end{array}$ & 69 & $52 \%$ & $5-9$ years & $\begin{array}{l}10-14 \\
\text { years }\end{array}$ & $\begin{array}{l}\text { Pathological } \\
\text { conditions }\end{array}$ & $\begin{array}{c}\text { Physiological } \\
\text { conditions }\end{array}$ & Present study \\
\hline $\begin{array}{l}\text { Kulubnarti } \\
\text { (Nubia) }\end{array}$ & $\begin{array}{l}6-15^{\text {th }} \\
\text { century }\end{array}$ & 324 & $76 \%$ & 4-7 years & $\begin{array}{l}14-16 \\
\text { years }\end{array}$ & $\begin{array}{l}\text { Early } \\
\text { childhood } \\
\text { stresses }\end{array}$ & $\begin{array}{l}\text { Adolescent } \\
\text { growth spurt }\end{array}$ & $\begin{array}{c}\text { Hummert and Van } \\
\text { Gerven, } 1985\end{array}$ \\
\hline $\begin{array}{l}\text { Unterseen and } \\
\text { Oberbueren } \\
\text { (Switzerland) }\end{array}$ & $\begin{array}{l}7-15^{\text {th }} \\
\text { century }\end{array}$ & 112 & $78 \%$ & 2 years & $\begin{array}{l}9-12 \\
\text { years }\end{array}$ & $\begin{array}{c}\text { Malnutrition, } \\
\text { weaning, } \\
\text { children } \\
\text { diseases }\end{array}$ & $\begin{array}{l}\text { Adolescent } \\
\text { growth spurt }\end{array}$ & Ameen et al., 2005 \\
\hline $\begin{array}{l}\text { Cedynia } \\
\text { (Poland) }\end{array}$ & $\begin{array}{l}10-14^{\text {th }} \\
\text { century }\end{array}$ & 324 & $74 \%$ & $\begin{array}{l}9-11 \\
\text { years }\end{array}$ & $\begin{array}{l}\text { M:11-12 } \\
\text { years } \\
F: 8-10 \\
\text { years }\end{array}$ & $\begin{array}{l}\text { Prepubertal } \\
\text { growth spurt }\end{array}$ & $\begin{array}{l}\text { Adolescent } \\
\text { growth spurt }\end{array}$ & Piontek et al., 2001 \\
\hline $\begin{array}{c}\text { Tomils } \\
\text { (Switzerland) }\end{array}$ & $\begin{array}{l}11-15^{\text {th }} \\
\text { century }\end{array}$ & 241 & $77 \%$ & 更 & $\begin{array}{c}\mathrm{M}: 9.5- \\
10.5 \\
\text { years } \\
\text { F : 8.3-9.3 } \\
\text { years }\end{array}$ & $\begin{array}{r}\text { HLs formed } \\
\text { sociocultural } \\
\text { prepubertal }\end{array}$ & $\begin{array}{l}\text { after } 7 \text { years: } \\
\text { changes and } \\
\text { growth spurt }\end{array}$ & $\begin{array}{c}\text { Papageorgopoulou } \\
\text { et al., } 2011\end{array}$ \\
\hline $\begin{array}{l}\text { Waterford and } \\
\text { Tintern } \\
\text { (Ireland) }\end{array}$ & $\begin{array}{l}11-17^{\text {th }} \\
\text { century }\end{array}$ & 73 & $36 \%$ & $10-11$ & years & $\begin{array}{r}\text { Poor health } \\
\text { Adolescent }\end{array}$ & $\begin{array}{l}\text { onditions and } \\
\text { growth spurt }\end{array}$ & Hughes et al., 1996 \\
\hline $\begin{array}{l}\text { Observance } \\
\text { and Delos } \\
\text { (France) }\end{array}$ & $\begin{array}{c}1720- \\
1722 \\
A D\end{array}$ & 113 & $64 \%$ & $\begin{array}{l}0-2 y \\
4-6 y\end{array}$ & $\begin{array}{l}\text { ears } \\
\text { ears }\end{array}$ & $\begin{array}{l}\text { Children } \\
\text { diseases }\end{array}$ & $\begin{array}{l}\text { Adolescent } \\
\text { growth spurt }\end{array}$ & Chaumoître, 2007 \\
\hline
\end{tabular}


Interpretations given here, regarding HLs origins and their impact on growth, need to be taken cautiously since they are deduced from modern growth patterns. The exact growth pattern at Dendermonde, in the late 16th century, is unknown, and it may have displayed distinct characteristics from the actual standards. For instance, it is possible that growth velocity was slower or more irregular than today and that growth spurts occurred earlier than the ones defined nowadays. Such discrepancies are plausible, but they cannot be detected by confronting dental ages with bone dimensions due to the small size of the Maria Troon skeletal sample. The implication of socioeconomical factors on growth is also a great limitation to the application of modern standards on archaeological sample (WHO Multicenter Growth Reference Study Group, 2006; Butte et al. 2007).

Despite these limitations, the results of the analysis suggest that HLs formed at different age periods may not reveal the same underlying factors. The early formed HLs could be linked to diverse causes, and mostly reflecting pathological conditions whereas the HLs formed around the puberty are more likely to be physiological and hormonal lines (Alfonso et al., 2005; Alfonso-Durruty, 2011; Papageorgopoulou et al., 2011; Gilde, 2013). Such interpretations need to be confirmed in the future by further analyses aiming to reconstructing growth patterns on larger osteological samples.

\section{Conclusion}

This study contributes to the question of the HLs etiology by providing new insights on the influence of HLs on bone parameters of archeological individuals. Its results suggest that the causes of HLs could be diverse, pathological or physiological, depending on the period of life during which they were formed. HLs should not systematically be considered as synonym of pathological arrest of growth, especially for those formed during puberty when the growth process is characterized by the adolescent spurt.

From now on and in future anthropological studies, the etiology of HLs should be interpreted depending on their age-at-formation. It would be important to distinguish the lines formed during a period characterized by stable growth from those formed during accelerated growth period (physiological lines). In the perspective of a paleopathological study on past population, it would be necessary to focus only on the former ones since lines of physiological origin are unlikely to represent the health impairments of a population.

Perhaps, a re-evaluation of the concept of stress is also needed (Reitsema and McIlvaine, 2014; Temple and Goodman, 2014). Anthropologists include under this umbrella term any disruptive 
event which leads to impairments, as arrest of bone or teeth growth. It is considered as the shadow face of adaptation (Goodman et al., 1998). However, the present study suggests that HLs following pubertal stage have a positive response on the growth dynamic. Thus, a stress indicator is not systematically synonym of negative impact on the organism.

To elucidate the etiology of HLs, the results obtained here need to be confirmed by further analyses, by applying similar methodological approach on larger osteological samples. Comparing HLs formed at different age with other stress indicators would be promising to precise the relationship between the lines and the health status.

Acknowledgements: The results of this research had been obtained from a master's thesis (A.B.) developed at the University of Bordeaux, within the PACEA laboratory (UMR 5199). The authors thank the Royal Belgian Institute of Natural Sciences (Brussels) for providing the skeletal material and the Royal Museum for Central Africa (Tervuren) for acquiring the radiographs. Gratefulness goes to the Maison des Sciences de l'Homme d'Aquitaine (Pessac) for funding this research. Thanks also go to the PACEA laboratory researchers for their help regarding radiographs treatment and statistical analyses; to C.R. Dyche and K. Bowgen for proofreading the article; and to the reviewers for their comments which contribute to the improvement of the paper.

Author contributions: This research was designed by DC, SK and CP for a master thesis developed at the University of Bordeaux. The data collection was executed at the Royal Belgian Institute of Natural Sciences (Brussels) by AB, with the assistance of SK and CP, and the data treatment was executed by $\mathrm{AB}$ at the University of Bordeaux. $\mathrm{AB}$ and SK both worked on the final version of the paper. 


\section{Literature cited}

Abraham A, Braham A, Macnicol MF. 2001. Growth arrest lines and recurrent patellar dislocation: a new sign. The Knee 8:163-165.

Acheson RM. 1959. Effects of starvation, septicemia and chronic illness on the growth cartilage plate and metaphysis of the immature rat. J Anat 93:123-134.

Alfonso MP, Thomson JL, Stande VG. 2005. Reevaluating Harris Lines - A comparison between Harris lines and enamel hypoplasia. Coll Antropol 29:393-408.

Alfonso-Durruty MP. 2011. Experimental assessment of nutrition and bone growth's velocity effects on Harris lines formation. Am J Phys Anthropol 145:169-180.

Ameen S, Staub L, Ulrich S, Vock P, Ballmer F, Anderson SE. 2005. Harris lines of the tibia across centuries: a comparison of two populations, medieval and contemporary in Central Europe. Skeletal Radiol 34:279-284.

Anderson M, Green WT, Messner MB. 1963. Growth and predictions of growth in the lower extremities, Journal Bone Joint Surg Am 45:1-14.

Arnay-de-la-Rosa M, Velasco-Vasquez J, Matrin-Rodriguez E, Gonzalez-Reimers E, CastillaGarcua A. 1994. Radiopaque transverse lines (Harris lines) in the Prehispanic population of El Hierro (Canary Islands). Anthropol Anz 52:53-57.

Beom J, Woo EJ, Lee IS, Myeung JK, Kim YS, Oh CS, Lee SS, Lim SB, Shin DH. 2014. Harris lines observed in human skeletons of Joseon Dynasty, Korea. Anat Cell Biol 47:66-72.

Blanco RA, Acheson RM, Canosa C, Salomon JB. 1974. Height, weight, and lines of arrested growth in young Guatemalan children. Am J Phys Anthropol 40:39-47

Bräuer G. 1988. Osteometrie. In: Knussmann R, Martin R, editors. Anthropologie: Handbuch der vergleichenden Biologie des Menschen. Stuttgart: Fisher. p 160-231.

Bruzek J. 2002. A method for visual determination of sex, using the human hip bone. Am J Phys Anthropol 117:157-168. 
Buikstra J. 1976. The Caribou Eskimo: general and specific disease. Am J Phys Anthropol 43:451-467.

Butler GE, McKie M, Ratcliffe SG. 1990. The cyclical nature of prepubertal growth, Annals of Human Biology 17:177-198.

Butte NF, Garza, De Onis M. 2007. Evaluation of the feasibility of international growth standards for school-age children and adolescents. J Nutr 137:153-157.

Byers S. 1991. Technical note: Calculation of age at formation of radiopaque transverse lines. Am J Phys Anthropol 85:339-343.

Castex D. 2008. Identification and interpretation of historical cemeteries linked to epidemics. In: Raoult D, Drancout M., editors. Paleomicrobiology: past humans infections. Heidelberg: Springer. p 49-54.

Castex D, Kacki S. in press, Demographic patterns distinctive of epidemic cemeteries in archaeological samples, in: Raoult D., Drancourt M. (eds), Paleomicrobiology of Humans, ASM Press.

Chaumoître K. 2007. Analyse des stries d'arrêt de croissance sur deux populations du XVIIIème siècle provenant des charniers de peste de Marseille et Martigues. In: Signoli M, Chevé D, Adalian P, Boëtsch G, Dutour O, editors. Peste : entre épidémies et société. Florence:Firenze University Press. p 83-88.

Clarke SK. 1982. The association of early childhood enamel hypoplasias and radiopaque transverse lines in a culturally diverse prehistoric skeletal sample. Hum Biol 54: 77-84.

Cohen J. (1960) A coefficient of agreement for nominal scales, Educational and Psychological Measurement 20, p 37-46.

Coqueugniot H, Weaver TD. 2007. Brief Communication: Infracranial Maturation in the Skeletal Collection From Coimbra, Portugal: New Aging Standards for Epiphyseal Union. Am J Phys Anthropol 134:424-437.

Cunningham CA, Stephen A. 2010. The appearance of Harris lines at the iliac crest. AXIS 2:1321. 
Dattani M, Preece M. 2004. Growth hormone deficiency and related disorders: insights into causation, diagnosis and treatment. Lancet 363:1977-1987.

Dreizen S, Spirakis CN, Stone RE. 1964. Influence of age and nutritional status on "bone scar" formation in the distal end of the growing radius. Am J Phys Anthropol 22:295-305

Dequecker J. 1976. Quantitative radiology: radiogrammetry of cortical bone. Br J Radiol 49:912-920.

Fiscella G. 2007. Bioarchéologie appliquée aux séries anthropologiques de peste, $\mathrm{PhD}$ thesis, Faculté de Médecine de Marseille, 164 p.

Fiscella G, Bennike P, Lynnerup N. 2008. Transverse - Harris Lines in a skeletal population from the 1711 Danish Plague site. Anthropol Anz 66:129-138.

Garn SM, Siverman FN, Hertozg KP, Rohmann CG. 1968. Lines and bands of increased density : their implication to growth and development. Med Radiogr Photogr 44:58-89.

Gelander L, Karlberg J, Albertsson-Wikland K. 1994. Seasonality in lower leg length velocity in prepubertal children. Acta Paediatr 83:1249-1254.

Gilde E. 2013. Stressed to the bone: Comparing stature and non-specific indicators of stress in a Dutch rural post-Medieval population. Bachelors of Arts. Archaeology Departement. Leiden University. 95 p.

Gill MS, Tillman V, Veldhuis JD, Clayton PE. 2001. Patterns of GH output and their synchrony with short-term height increments influence stature and growth performance in normal children. J Clin Endocrinol Metab 86:5860-5863.

Gindhart PS. 1969. The frequency of appearance of transverse lines in the tibia in relation to childhood illnesses. Am J Phys Anthropol 3:17-22.

Gonzalez-Reimers E, Perez-Ramirez A, Santolaria-Fernandez F, Rodriguez-Rodriguez E, Martinez-Riera A. 2007. Association of Harris lines and shorter stature with ethanol consumption during growth. Alcohol 41:511-515.

Goodman AH, Clark GA. 1981. Harris lines as indicators of stress in prehistoric Illinois populations. In: Martin DL, Bumsted MP, editors. Biocultural adaption comprehensive 
approaches to skeletal analysis. Research Report No. 20. Amherst: Department of Anthropology, University of Massachusetts. p 35-46.

Goodman AH, Thomas RB, Swedlund AC, Amerlagos GJ. 1998. Biocultural perspectives on stress in prehistoric, historical, and contemporary population research. Yearb Phys Anthropol 31:169-202.

Grolleau-Raoux JL, Crubézy E, Rougé D, Brugne JF, Saunders SR. 1997. Harris Lines: a study of age-associated bias in counting and interpretation. Am J Phys Anthropol 103:209-217.

Goudie Falckenbach E, Ryssaert C, Brion M, Castex D, Rouzic M, Colombo A, Kneuvels D. 2012. Archeologisch onderzoek in Dendermonde op de site van het voormalige Birgitinessenklooster Maria Troon. Archeologia Medievalis 35:142-149.

Hadjouis D, Amar N. 2009. Hypoplasies linéaires de l'émail dentaire et lignes de Harris appliquées à une population protestante du XVIIème siècle (Cimetière de Saint-Maurice, Valde-Marne). Biom Hum Anthropol 27:121-127.

Harris HA. 1931. Lines of arrested growth in long bones in childhood: the correlation of histological and radiographic appearances in clinical and experimental conditions. Br J Radiol 4:622-640.

Himes JH. 1978. Bone growth and development in protein-calorie malnutrition. World Rev Nutri Diet 28:143-187.

Hughes C, Heylings DJA, Power C. 1996. Transverse (Harris) lines in Irish archaeological remains. Am J Phys Anthropol 101: 115-131.

Hummert JR, Van Gerven DP. 1985. Observations on the formation and persistence of radiopaque transverse lines. Am J Phys Anthropol 66:297-306.

Hunt EE, Hatch JW. 1981. The estimation of age at death and ages of formation of transverse lines from measurements of human long bones. Am J Phys Anthropol 54:461-469.

Khadilkar VV, Frazer FL, Skuse DL, Stanhope R. 1998. Metaphyseal growth arrest lines in psychosocial short stature. Arch Dis Child 79:260-262.

Landis JR, Koch GG. 1977. The measurement of observer agreement for categorical data, Biometrics, 33:159-174. 
Lampl M., Johnson M.L. 1997. Identifying saltatory growth patterns in infancy: a comparison of results based on measurement protocol. Am J Hum Biol Biol9:343-355.

Lewis ME. 2006. The bioarchaeology of children. Perspectives from biological and forensic anthropology, Cambridge University Press. p 13-19 and 66-68.

Lewis ME, Roberts C. 1997. Growing pains: the interpretation of stress indicator. Int J Osteoarchaeol 7:581-586.

Maat GJR. 1984. Dating and rating of Harris's lines. Am J Phys Anthropol 63:291-299.

Marceau K, Ram N, Houts RM, Grimm KL, Susman EJ. 2011. Individual differences in boys' and girls' timing and tempo of puberty: modeling development with nonlinear growth models. Dev Psychol 47:1389-1409.

Maresh MM. 1970. Measurements from roentgenograms. In: McCammon RW, editor. Human growth and development. Springfield. p 157-200.

Margerison BJ and Knüsel C. 2002. Palaeodemographic comparison of a catastrophic and an attritional death assemblage. Am J Phys Anthropol 119:134-143.

Mays SA. 1995. The relationship between Harris lines and other aspects of skeletal development in adults and juveniles. J Archaeol Sci 22:511-520.

McHenry H. 1968. Transverse lines in long bones of prehistoric California indians. Am J Phys Anthropol 29:1-18.

Moorrees CFA, Fanning EA, Hunt EEJ. 1963. Age variation of formation stages for ten permanent teeth. J Dent Res 42:1490-1502.

Murail P, Bruzek J, Houët F, Cunha E. 2005. DSP: a tool for probabilistic sex diagnosis using worldwide variability in hip-bone measurements. Bull Mém Soc Anthropol Paris 17:167-176.

Nowak O, Piontek J. 2002. Does the occurrence of Harris lines affect the morphology of human long bones? HOMO 53:254-276.

Nowak O, Piontek J. 2011. Does the presence of Harris lines affect the final stature in a medieval population. Anthropologie XLIX:119-125. 
Ortner DJ. 2003. Identification of Pathological Conditions in Human Skeletal Remains. San Diego:Academic Press. p 119-177.

Owings-Webb PA, Suchey PM. 1985. Epiphyseal union of the anterior iliac crest and medial clavicle in a modern multiracial sample of American males and females. Am J Phys Anthropol 68:457-466.

Papageorgopoulou C, Sutre SK, Ruhli FJ, Siegmund F. 2011. Harris lines revisited : prevalence, comorbidities, and possible etiologies. Am J Hum Biol 23:381-391.

Park EA. 1964. The imprinting nutritional disturbance on growing bones. Paediatrics 29:815862.

Park EA, Richter CP. 1953. Transverse lines in bone: the mechanism of their development. Bull Johns Hopkins Hosp 93:234-248.

Piontek J, Jerszinska B, Nowak O. 2001. Harris lines in subadult and adult skeletons from the Mediaeval cemetery in Cedynia, Poland. Var Evol 9:33-43.

Reitsema LJ, McIlvaine BK. 2014. Reconciling "stress" and "health" in physical anthropology: What can bioarchaeologists learn from the other subdisciplines? Am J Phys Anthropol 155:181185.

Ribot I, Roberts C. 1996. A study of non-specific stress indicators and skeletal growth in two mediaeval subadult populations. J Archaeol Sci 23:67-79.

Rogol AD, Roemmich JN, Clark PA. 2002. Growth at puberty. J Adolesc Health 31:192-200. Sajko S, Stuber K, Wessely M. 2011. Growth restart / recovery lines involving the vertebral body: a rare, incidental finding and diagnostic challenge in two patients. J Can Chiropr Assoc 55:313-317.

Saunders SR, Hoppa RD. 1993. Growth deficit in survivors and non-survivors: biological mortality bias in subadult skeletal samples. Yearb Phys Anthropol 36:127-151.

Sutter R. 2003. Nonmetric subadult skeletal sexing traits. I. A blind test of the accuracy of eight previously proposed methods using prehistoric known-sex mummies from Nothern Chile. J For Sci 48 927-935. 
Tanner JM. 1960. Human growth. London:Pergamon press. 120 p.

Temple DH, Goodman AH. 2014. Bioarcheology has a "health" problem: conceptualizing "stress" and "health" in bioarcheological research. Am J Phys Anthropol 155:186-191.

Teele RL. 1999. Femoral growth lines: bony birthmarks in infants. Am J Roent 173:719-722.

Thalange NKS, Foster PJ, Gill MS, Price DA, Clayton PE. 1996. Model of normal prepubertal growth. Arch Dis Child 75:427-431.

WHO Multicentre Growth Reference Study Group. 2006. WHO Child Growth Standards based on length/height, weight and age. Acta Paediatr 450:76-85. 